\title{
Housing and the Creation of Home for Refugees in Western Australia
}

\begin{abstract}
FARIDA FOZDAR* \& LISA HARTLEY**
* Anthropology and Sociology, University of Western Australia, Perth, Australia ** Centre for Human Rights Education, Curtin University, Perth, Australia

Safe, appropriate housing is vital for the successful settlement of refugees, since establishing a home is part of the process of redeveloping a sense of ontological security. However humanitarian entrants in Australia have a far greater likelihood of moving multiple times in the early years of settlement and are far less likely to be purchasing their homes compared to other migrants. Using data from interviews, focus groups and a photovoice exercise, positive home-building experiences of refugees are illustrated, while factors leading to negative outcomes are also identified. The more positive story came from the photovoice exercise with images of the remaking of home as a place of connection with others, of personal pride, of comfort and leisure, of family and commensality. Interview and focus group data focused on structural issues including the cost of housing, limited choice in the rental market, lack of public housing, poor quality, negative attitudes of real estate agents, lack of access to services, and complex tenancy procedures which are key factors influencing insecurity of tenure. The effects on refugees' sense of ontological security are discussed.
\end{abstract}

Key Words: Housing, Refugees, Australia, Ontological security, Home 


\section{Refuges, Housing and the (Re) Creation of Ontological Security}

It has been argued that the creation of a new home is vitally important for refugees' sense of belonging (Brun 2001; Sampson and Gifford 2010) - the aphorism that "one's house is one's home" is particularly apt for those who have come from situations of extreme insecurity and been denied access, often intentionally, to a stable home of origin. Indeed, Edward Said defines exile as an enforced rift "between a human being and a native place, between the self and its true home" $(2000,173)$. While the idea of a "true home" is problematic, and displacement is not inevitably pathological (Malkki 1992), the importance of the security that comes with place cannot be underestimated, particularly for this segment of the community.

Traditionally, home has been conceptualized as a stable, physical centre of an individual's universe, a safe place from which to leave and to return, and a principal focus of one's concern (Ahmed et. al. 2003; Blunt and Dowling 2006). It is seen as a right or entitlement (Rapport and Dawson 1998,7) and is associated with identity formation (Cooper Marcus 1997; Netto 2011). Home is not simply about one's abode, although one's house is one part of it, but also the relationships there-in (Hiscock et al. 2001; Kearns et al. 2000). Home is associated with a set of communitarian practices linked with a pattern of regular activities, material things and physicalspace, and is positively evaluated normatively (Douglas 1991). Home is also associated with family. There is a strong emotional aspect to home - it is seen as a place of belonging, solidarity, comfort, support and warmth (Blunt and Dowling 2006; Cooper Marcus 1997). Since home is more closely linked with a particulartype of relationship and feelings than a specific material space, one could argue that it is more a social than a territorial concept. Yet the two are inextricably linked, for it is the association with territory that gives meaning to the notion and provides the locus around which emotions and relationships revolve. Architects have mapped the ways in which one's immediate physical surroundings, such as one's house and gardens, fundamentally affect one's emotions and behaviors, and impact one's social engagement (Cooper Marcus 1997) and the physical and mental health impacts of appropriate housing are well known (Searle, Smith, and Cook 2009). In an analysis of the ways in which "house" and "home" are linked Easthope (2004), borrowing from Heidegger and Bourdieu, uses the concept of "place" to connect the two, arguing that "home" is a significant type of "place" the positive construction of which involves physical space and social and emotional connection, affecting (and effecting) identity and well-being.

Some have argued that this conceptualization of home, one that is linked to territory/space, and therefore to housing, is an achronistic (Rapport and Dawson1998). In postmodernity, it is suggested, home is fluid, mobile, and shifts with multi-valanced and transnational identities. While home remains linked with 
identity, it is the self rather than place, which is at the centre. In this perspective, the individual moves between multiple homes, and is at home in continuous movement. Place, and home as a subset of place, thus becomes a point where social relations and activities, unfettered by time and space, intersect (Massey 1995).

One reason for the turn away from the presumption of a fundamental connection between home and place is that the idea of home, and of identities as essentially linked to "home" territory, particularly national territory, has been the source of mostof the violence of the twentieth (and now twenty-first) century. This has led some tosuggest that refugees, having been forced to breach this connection, are less in need of a sense of home, than others. It has been argued that their experiences produce amore cosmopolitan outlook, less rooted to territory (Pollock et al. 2000). However, some recognition of the importance of place to the individual, refugee or otherwise, is necessary, not least because both rights and belonging generally remain grounded in territory and the claims one can make to that territory (Calhoun 2007; Fozdar and Hartley, in press; Sampson and Gifford 2010, 117). Thus appropriate, secure housingin countries of resettlement, while not in itself sufficient for making a "home", is a vital precondition in providing refugees with a place from which to begin to re-establish themselves, to resettle successfully. This is particularly important given the situations from which refugees are fleeing, and their experiences on their journeys to safety and in refugee camps, which by definition include the loss of both house and home (Ager 1999; Ferguson and Pittaway 1999; Fozdar 2012; Ingleby 2005; Ward, Bochner, and Furnham 2001). Indeed housing is identified as one of ten key domains (Ager and Strang 2008) necessary for successful settlement and integration, seen as attaining "a degree of self-sufficiency, to participate in the social and economic life of the community and to retain what might be described ... as a degree of personal identity and integrity" (Goodwin-Gill 2009, 38). Ager and Strang note that the more material aspects of settlement, such as housing, along with employment, education and health, are to some extent built upon social connections, which are facilitated by language, cultural knowledge, safety and stability, and a foundation of rights and citizenship. These domains are interconnected, generating a successful integrated settlement process.

One aspect of the remaking of home is the re-establishment of what Giddens, adopting psychologist R.D. Laing's phrase, has called "ontological security". This is the secure sense of oneself and one's place in the world that is an aspect of being human. Laing's interest was in the loss of ontological security resulting from mental illness and Giddens' in its remaking following cataclysmic ruptures in an individual's life. Ontological security is based in knowledge of how to meet one's needs (Giddens 1993b, 124) and results from the trust we have in our surroundings, both human and non-human (Noble 2005). This knowledge 
provides a basic understanding of how to "be" in the world, and is linked to constancy and trust (Hiscock et al. 2001). When this knowledge is profoundly disrupted, through "critical situations" where routine grounding is radically dislocated, this can lead to ontological insecurity, which is both a disruption of the cognitively ordered world of self and other, and the management of individual wants.

Scholars such as Cooper Marcus (1997) and Saunders (1990) have identified the home as key to providing ontological security, while Dupui and Thorns (1996) demonstrate that home is vital for ontological security among older people and Padgett (2007) argues that secure housing is vital for ontological security among those with a mental illness. Using Shaw's (2004) distinction between the "hard" aspects of housing (material aspects of a dwelling) and "soft" aspects (the sense of at-homeness subjectively experienced), Padgett suggests "the latter connotes "ontological security", the feeling of well-being that arises from a sense of constancy in one's social and material environment which, in turn, provides a secure platform for identity development and self-actualization" (2007, 1926). This is partly the result of having a space in which to develop daily routines and gain a sense of control over one's life.

The relationship of housing and home to ontological security has been outlined by Dupuis and Thorns $(1998,29)$. One's house becomes a home, providing ontological security, when it is a place of constancy (materially and socially), where day-to-day routines are performed, where people feel in control of their lives, and where it provides a secure base within which identities can be constructed (see also Hiscock et al. 2001). Threats to the development of these functions are to be found particularly where housing is insecure, requiring regular movement or negative interactions with landlords and so on. Security of place enables the foundation on which to build other aspects of a stable, workable life.

Recognizing some of these issues, the United Nations (UN) identifies secure, habitable and affordable housing as a basic human right (UN 1991). As noted, for refugees, housing is often listed as one of the crucial elements in successful settlement (Ager and Strang 2008; Valtonen 2004). Successful settlement includes four key goals - restoring safety; attachments and social connections; meaning; and dignity (United Nations Higher Commissioner for Refugees [UNHCR] 2002), all of which can be related to housing, as an aspect of "home-making" and the development of ontological security. However, it has only been in the last few yearsthat research on the experiences of refugees resettling in Australia in accessing stable housing and the factors influencing movement has been undertaken (see ASeTTS 2008; Berta 2012; Burgermeister, Kitching, and Iscel 2008; Forrest et al.2012; Tilbury et al. 2005). This recent interest is partly the result of a growing level of concern among service providers that housing has 
become perhaps the key settlement challenge in recent years (RCOA 2010; SCOA 2012), influencing refugees'ability to make Australia home.

\section{Refugees and Housing in Australia}

Australia has a large migrant population. Among those moving to Australia each year are 13,750 humanitarian entrants, around $10 \%$ of the total migrant intake annually. Unlike many countries which have seen a significant economic downturnin recent years, Australia has avoided recession and with its booming economy, fuelled by the mining sector which exports to China, retains a high level of demandfor migrants, including temporary migrants. Its infrastructure has struggled to keep up with the inflow, producing pressures on a variety of fundamental needs, particularly housing.

As a result, in the last decade housing has become extremely expensive. According to an International Housing Affordability survey conducted in 2011 in Australia, Canada, China, Ireland, New Zealand, the UK and the USA, out of 81 major cities (defined as having a population of 1 million people or more), six of Australia's capital cities were ranked in the top 20 most unaffordable for home purchasing (Demographia 2011). Sydney and Melbourne were ranked 3rd and 4rd, and Perth 16th. Australia exhibited the worst housing affordability of any nationalmarket outside Hong Kong. There were no affordable markets, and the majority were classified as severely unaffordable.

In monetary terms, median house prices in Australia in the past decade have increased $147 \%$ which far exceeds the $50 \%$ rise in average incomes since 2001.This has resulted in a ballooning of the housing price-income ratio from a manageable though high 4.7 in 2001, to 7.3 in 2012 (well over the 5 signifying "unaffordable" (Phillips 2012).

Lack of affordability in the rental market demonstrates similar trends. Rental affordability worsened considerably between 2007 and 2010 (COAG 2011). Nationally, affordability worsened for the lowest $10 \%$ of households with rentalstress increasing from $49.2 \% 2007$ to $60.8 \%$ in 2010. In capital cities, this proportion was higher; $45.2 \%$ of low-income households were in rental stress in 2010, an increase from $38.1 \%$ in 2007 . Rental vacancy rates are at an all-time low and there is a critical shortage of social (public) housing, with tightening eligibility criteria and lengthening waiting times (RCOA 2010).

As experienced by refugees and asylum seekers in other developed nations such as the UK (e.g. Netto 2011; Zetter and Pearl 1999), UNHCR-approved humanitarian entrants to Australia find themselves caught up in this difficult market. While initially some support is provided, this appears inadequate in the longer term. After arrival in Australia, refugees have access to a range of 
government-funded services designed to provide material, social and emotional assistance. In terms of housing, four weeks of free accommodation is provided for refugees processed offshore, and then assistance with accommodation costs, as well as housing services, including help finding suitable long-term housing, assistance with leasing and connection to services like electricity, gas and the telephone, provision of household goods such as a fridge, washing machine, TV and beds, and information about household care and cleanliness are provided. No government-provided accommodation is offered, leaving the sector reliant on private rental accommodation. Those who come as sponsored entrants (just under half the quota) are expected to receive a similar level of assistance from their proposers, who are often refugees themselves. ${ }^{1}$

In most capital cities, refugees tend to cluster in areas that are hubs for dedicated services such as English language education centres and migrant resource centres. While traditionally inner-city suburbs were common places of first settlement, these are now unaffordable. In Melbourne, for example, refugees are located in outer suburbs characterized by cheaper housing and poor infrastructure and transport (Sampson and Gifford 2010). In Western Australia, where the current research was undertaken, refugee populations are significant in middle and outer regions of the capital city, Perth, making up visible populations in several northern and southern suburbs. Some have also moved to smaller urban centres in other parts of Western Australia.

As research in other countries has found (Netto 2011; Phillips 2006; Robinson, Reeve, and Casey 2007; Sherrell et al. 2007), refugee housing in Australia is insecure. A typical housing pattern for a refugee in Australia includes: arrival in Australia and housing within government-provided on-arrival accommodation; movement into private rental accommodation 30 days after arrival, typically a low-cost flat; a number of subsequent moves within the rental

\footnotetext{
${ }^{1}$ Australia's humanitarian entrants can be classified into three groups, those who meet the UNHCR definition of a refugee and who are processed offshore and brought to Australia under its resettlement program (this group gets the greatest level of settlement assistance); those who do not quite meet the UNHCR standard but are still under threat of persecution and who have family already in Australia (sponsored entrants); and those who arrive in Australia and subsequently claim refugee status (during the time this study was undertaken such applicants who arrived by boat without a visa were detained until their refugee status was determined). This latter group, known as asylum seekers, do not have access to many of the services the others do. It is difficult to compare the situation for refugees in Australia with other Western countries due to differential access to government assistance, and because many published studies on housing elsewhere focus on asylum seekers, i.e. those whose refugee status has yet to be determined, known as "Refugee Claimants" in the Canadian context (see, for e.g. Murdie 2005; Sherrell, D'Addario, and Hiebert 2007).
} 
market, commonly to larger housing that may be cheaper and closer to friends, relatives and other members of their communities; and possible exit to public rental housing or long-term private rental (Beer and Foley 2003). Similar pathways have been found specifically for refugees from Africa (Winkler n.d.). Three-quarters of refugees rent privately or use community housing and move three times, on average, in their first year after arrival (Beer and Foley 2003). In a study based on 1999/2000 data from the Longitudinal Survey of Immigrants to Australia (LSIA), Forrest et al. (2012) found that most humanitarian entrants initially live with family or friends before moving into long-term private rental accommodation, although the experience differs by ethnic community. It is unclear whether this level of housing instability is seen as a problem by refugees, or whether it is their choice. Despite their lack of access to the home purchasing market, humanitarian entrants to Australia were found to be mostly satisfied with their housing situation (Forrest et al. 2012). It is possible that this may have changed in the last decade as access to appropriate rental accommodation and the prospect of ever owning one's home become more difficult. The 2006 Australian Census data show that humanitarian entrants are far less likely to be purchasing their own homes five years after arrival than migrants from other visa categories (Hugo 2011). This may indicate the difficulty in the early years of establishing language competency, education and employment, but is most likely also related to the massive price increases, in the context of refugees' marginal position. The fact that refugees, at least in the early years of settlement, tend to have lower income levels than the Australian average, with many earning below the official poverty line (Sampson and Gifford 2010), severely limits their housing opportunities.

Homelessness vulnerability is a growing trend among refugees in other developed nations (Kissoon 2010; Phillips 2006; Robinson, Reeve, and Casey 2007; Sherrell et al. 2007), although cross-country comparisons are difficult due to different definitions of, and servicing levels for, refugees as opposed to asylum seekers. In Australia, research identifies refugees as a group vulnerable to housingcrisis and/or homelessness (Beer and Foley 2003). While humanitarian entrants facethe same problems as many other low-income households, they are doubly disadvantaged through a lack of knowledge of the language, customs and strategies to access housing (Beer and Foley 2003). In terms of governmentfunded housing, no data are collected on the number of refugees and humanitarian entrants on public housing waiting lists (waiting times in Perth are currently nine years, two years ifurgent). However, evidence suggests that when faced with primary homelessness (i.e. not having a roof over one's head), refugees often stay with friends or family, resulting in overcrowding, family conflict and high levels of stress (Flanagan 2007).

Research exploring the housing experiences of refugees in Australia 
consistently identifies a number of barriers, some of which are shared by others on low incomes, some of which are refugee specific (Abu-Duhou 2006; Atem and Wilson 2008; Australian Survey Research Group 2011; Beer and Foley 2003; Berta 2012; Coventry et al. 2002; Flanagan 2007; Forrest et al. 2012; Kelly 2004; Pendergast2007; Ransley and Drummond 2000; WEAOC 2010). These include: a lack of affordable housing in the private rental market; the tightening of eligibility for public housing; long waiting lists for public housing; a decrease in public housing stock; a lack of knowledge regarding tenancy issues; the need to be employed; lackof capital and low incomes; difficult application processes due to lack of rental history/referees and identification, and discrimination from landlords and real estateagents (especially for those more obviously "visibly different"); difficulty housinglarge families, and single men; unrealistic expectations; the after-effects of torture and trauma; and the inflated Australian real estate market. Research conducted in the UK (Phillips 2006; Zetter and Pearl 1999) and Canada (Carter, Polevychok, andFriesen 2009; Francis 2009; Murdie 2005; Murdie et al. 1995; Sherrell et al. 2007) has found similar barriers are experienced by refugees and asylum seekers there, although the housing markets are less tight. Humanitarian entrants in Australia are increasingly in need of legal assistance for issues related to housing. ${ }^{2}$

\section{Housing, Refugees and Ontological Security in Western Australia}

This paper offers a qualitative complement to a recent contribution by a team of geographers analysing data on refugee housing from the 1999/2000 LongitudinalSurvey of Immigrants to Australia which maps housing outcomes in the first 18 months after settlement (Forrest et al's 2012). The source countries have changed significantly since that data was collected, with very few former Yugoslavs now arriving, and greater proportions of East Africans and Burmese, and people from Middle Eastern backgrounds. The newer cohort are more "visibly different" thanthe earlier groups, exacerbating the challenges they face in the housing market. Another key change has been the cost of housing, which, as

\footnotetext{
${ }^{2}$ As a result of such problems, an African Legal Service was established in Victoria in 2007. It produced a report (Fraser 2009) that identified some of the most common legal problems requiring assistance: homelessness and support in finding accommodation; appealing decisions (e.g. that the client did not qualify for emergency housing); questions about a "notice to vacate"; questions about the landlord's right to sell a property or arrange inspections; questions about a landlord's responsibility to repair a property, and the tenant's ability to withhold rent if the property is not repaired. The report concluded that the majority of the queries arose from the tight rental market and lack of public housing rather than legal issues. Many resulted from a lack of familiarity with the procedures and laws around renting residential property (e.g. the need to complete a detailed condition report on entering into a lease). The same organization undertook a follow-up study which details many cases of mistreatment by landlords (Berta 2011).
} 
reported, is nowamong the least affordable in the developed world. More important, however, are the methodological differences. Through direct engagement with the spoken wordand images offered by refugees, this paper provides a deeper insight into the lived experience of housing and the (re)creation of home among this sector of the population, paying particular attention to their sense of ontological security.

Thus, this paper seeks to answer the following questions:

- How is the recent cohort of humanitarian entrants in Australia faring in the tightening housing market?

- How do humanitarian entrants perceive their housing experiences and how are these related to homebuilding and the ontological security it implies?

\section{Method}

The qualitative research design used in-depth interviews, focus groups and "photovoice" to triangulate the settlement experience of refugees in relation to housing in Western Australia. Data were collected between April and November 2011.

\section{Data Collection}

\section{Humanitarian Entrant Interviews}

Interviews were undertaken in participants' preferred language by trained bilingual workers. Seventy-six humanitarian migrants (35 male, 41 female) who had arrived in Australia within the last four years participated. Thirty-five were from African countries, 27 from Middle Eastern countries, 12 from Burma and 2 from Sri Lanka. A broad range of ages was represented.

The bilingual workers followed a semi-structured interview schedule that asked questions relating to participants' experiences in Australia with regard to education and training, employment, health, housing, belonging, integration, citizenship and social networks. ${ }^{3}$ Interviews were recorded, translated and transcribed verbatim. This paper focuses on the data on housing.

\footnotetext{
${ }^{3}$ As part of the interview, participants were asked to complete a table detailing housing and family composition. This would have provided information about the numbers of and relationships between people living together. Despite bilingual assistant training, the data obtained were too unreliable to use. For instance, there was much incomplete data and information that was provided often did not match the content of the interviews. This data was therefore unfortunately unusable.
} 


\section{Photovoice Training And Methodology}

Photovoice provides visual data allowing participants to represent their experiences in a medium other than language (see for e.g. Joanou 2009; Karlsson 2001; Morrow 2001; Prins 2010; Wang and Redwood-Jones 2001). A subsample of 10 self-selected families participated in the photovoice project, five from Middle Eastern countries, three from Burma and two from African countries.

Participants attended a three-hour training session to learn basic digital camera skills, such as zooming, using the flash and deleting photographs (although some already had considerable skills). Through a series of interactive exercises, the participants discussed how to use photography to capture their settlement experiences creatively and were briefed on the importance of gaining the consent of those whose photographs they took. Participants were asked to take at least five photos on each of the following themes, over a period of three weeks: my home; my learning experiences; my employment experiences; my friendships; my life in Australia; and where I feel I belong. Three weeks was considered an appropriate length of time to ensure participants could address the range of themes (e.g. Going to work places, or employment agencies used, illustrating a range of aspects of life in Australia such as engagement with community groups, etc.) in the course of going about their daily lives. There was no suggestion from participants that thisperiod was too long, nor did the researchers find it impeded the completion of thetask in any way. The participants took 445 photographs (60 of which were excluded because they did not adhere to one of the research themes or have an obvious link with the research questions).

On completing the task, a debriefing meeting was arranged during which participants discussed the meaning of each photograph with the researchers. Participants were asked questions such as which theme each of the photos was responding to, what the photos represented and how each photo made them feel. If the participant felt confident to speak in English, the discussion was recorded verbatim in English. For those who required an interpreter, the discussion was recorded in English in thewords of the interpreter.

\section{Service Provider Focus Groups}

Three focus groups were conducted with service providers, facilitated by the researchers. Representatives from eight service providers, two government departments, one training organization, one representative group and the police took part. The focus groups were audio recorded and transcribed verbatim. Questions focused around perceptions of key issues in settlement. 


\section{Data Analysis}

Analysis of the transcript data was undertaken by the researchers independently coding a sample of transcripts for major themes. Categories were compared, then re-examined and refined. The aim of refining these categories was to maximize both internal homogeneity and external heterogeneity (Gilbert 2001; May 1997). All transcripts were then imported into the qualitative data analysis programme QSR NVivo11 using these codes, and relationships between the categories examined. A similar method of analysis was used for the focus group transcripts. Analysis of the photographs was undertaken through a selection of photographs that represented common themes, or that were particularly poignant, creative or communicative in their imagery. A semiotic analysis of the representation of the home space was undertaken toexplore the ways in which identity, emotion and social connections were signified. This included sense of self, safety, pride, networks, family and so on.

\section{Ethical Considerations}

Undertaking research with humanitarian entrants requires a heightened focus onethical issues (Jacobsen and Landau 2003; Journal of Refugee Studies 2007; Mackenzie, McDowell, and Pittaway 2007). A number of strategies were implemented to ensure the protection of the rights and safety of the participants. Prior tothe commencement of the interview participants were given an information sheet, which the bilingual worker explained in the appropriate language. Participants were also informed that their participation was voluntary and if they did consent to participate, they were free to withdraw from the study or decline to answer any question without consequence. Due to language barriers and potential illiteracy, participants were invited to give verbal, rather than written consent. Service provider agency staff provided written consent.

Confidentiality was also an important ethical consideration. All bilingual workers signed a pledge of confidentiality developed for the study. Additionally, any identifying information evident in interviews was deleted.

A number of ethical issues were considered specifically for the photovoice project. Wang and Redwood-Jones (2001) identify a number of ethical consideration relevant to this method, including: the right to privacy of people in both private and public spaces; recognition of the difference between legal and ethical actions in photographing people in public spaces; the importance of participants understanding when consent is needed; issues around safety; and the question of ownership. Additional issues include those around power and representation, such as the validity of participants' "informed" consent (Karlsson 2001), the possibility of self-representation that reproduces dominant hegemonies (Joanou 2009), and the potential for photography to be a tool for surveillance 
(Prins 2010). Since the visual data were considered to be an important and innovative part of the project, it was important to consider these ethical concerns. We did this by attempting to provide as much clarity and protection as possible. In the participant consent form, it was made clear that the photographer ultimately owns the photos and therefore their consent was required for the researchers to use the photographs in research reports, published articles or as part of a photo display planned as part of the report launch. In the consent form, participants were also told what the implications of publication of the photos were in terms of anonymity: e.g. by giving consent to use the photographs for publication, they could be used in the public domain and that the images would be identifiable and as such, associated with refugee status. Two participants did not include photographs of themselves. Participants were offered a camera as a token of appreciation for their participation along with some prints of their photos. This may have served as an incentive for some. In regard to photographs of third persons, during the training session, as well as in the consent form, participants were informed that it was their responsibility to ask people for their verbal consent to take photographs.

\section{Limitations}

As this study used a qualitative research design, and while we aimed to obtain views from a diverse range of people, the intent was not to seek a strictly representative sample of individuals from refugee backgrounds. Obtaining such a sample is almost impossible. However, we endeavoured to replicate the proportions settling from each region. The main goal was to collect in-depth, rich information from a range of refugee settlers.

The study provides information about the characteristics of settlement experiences of humanitarian entrants (in their own voices), but, being a qualitative study, does not attempt to quantify the prevalence of these experiences.

Additionally, due to differences between bilingual assistants, the quality of the interviews and translated transcripts varied.

Limitations with the photovoice component centred around the differences in photography skills and creativity between different participants, together with a general tendency to represent material aspects of settlement, rather than social or emotional aspects.

\section{Results}

This paper focuses on a key feature of the data in relation to housing - the importance and positive rebuilding of home represented predominantly in the photovoice exercise, but the simultaneously negative aspects associated with its 
insecurity, as evidenced in frequency of movement and various other challenges. Given the evidence of the importance of place, and housing in particular, for the redevelopment of ontological security and successful settlement, these findings are significant.

\section{Remaking Home}

The photovoice exercise produced predominantly positive images of the remakingof home, demonstrating the ways in which refugees were making the best of what-ever housing situation they found themselves in. The images represented both the material and the social aspects of home and home-making.

\section{Material Security}

A key feature of the material aspect was the pride and gratitude expressed inrelation to images of what would, for most Australians, be relatively modest, even undesirable, housing characteristics.

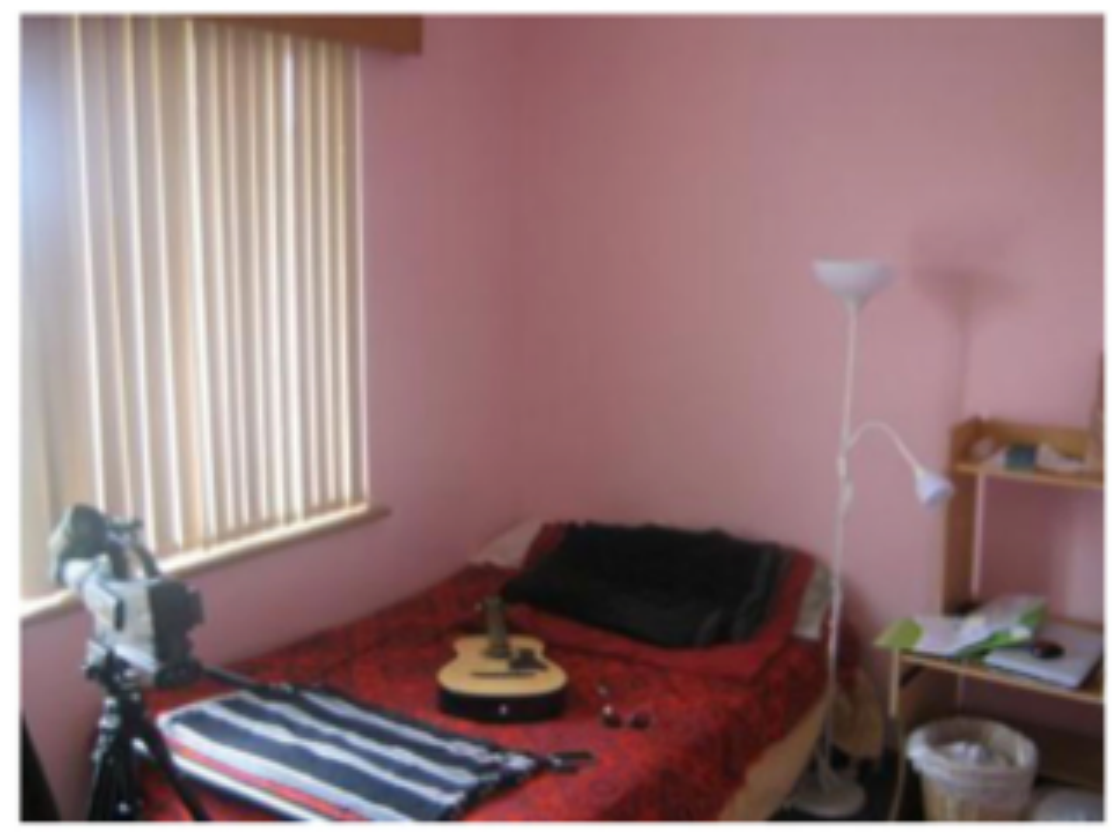

Figure 1. Image taken by male, Burma, 3 years in Australia. He is 19 years old and lives in the three-bedroom house with his grandparents, parents, sister and cousin.

For many participants, their new homes in Australia were greatly appreciated and seen as providing a safe haven both physically and emotionally. For example, in Figure 1, a young Karen (Burmese) man represents his home through a photograph of his bedroom, which is in a house he shares with his siblings, parents and grandfather. He described this room as providing him with safety and security, 
giving him privacy and the ability to work and study. More broadly, he likes "the strength of the house. This is a good community, it is safe, silent at night" ${ }^{5} \mathrm{He}$ said about his home, "Here I am happy". The photograph shows a typical, if simply furnished, young person's bedroom, containing, in centre space, material objects that this young man hopes will play a part in his future - his guitar and his camera. He explained that he hopes to become a cameraman or a musician, noting that Australia provides such opportunities that would not have been available to him in his country of origin: "I want to be a movie editor. I dream about it. We can do anything in Australia, anything is possible - I could be a doctor if I wanted". While the size and colour (pink) of the room, the simplicity of the furnishings, or the fact that the house was being shared with a number of people, could be cause for complaint, none was made. He said "I spend most of my time in my room. Before this I was in a refugee camp in Thailand. My bedroom is large. I like the colour. I spend a lot of time in there. I like my privacy". This was clearly his sanctuary - it is "safe", "strong", "private" and "silent at night". The same participant included a photograph of his shower among his photos of "home", noting that this was an alien piece of technology that he had had to adjust to, having been used to washing in the river. He said "This home is very different to in my country. We used to go to river and get water. Now we can have a shower and know we're safe. We had no privacy, now I can have privacy". For him, then, home represented sanctuary, opportunity, and adjustment.

As noted, images of quite modest houses, by Australian standards, were taken proudly, to demonstrate successful settlement. For example, one older Burmese man took a photograph of a simple red brick duplex, saying "I'm happy in Australia. I show friends in Burma these pictures [of my house]. This is my life. I want to post it to friends in the camp". The desire to send the picture to friends still living in the refugee camp illustrates the pride felt, and the developing sense of place being established. For several participants, something about the solidity of brick housing was important for their sense of security. This gentleman also said of another image of his house "This is my home. We are happy to get this property. We clean the garden. It's like Burma but no flowers - I planted the flowers. I feel proud - I want to plant and grow". He is clearly investing in his home on the assumption that, despite it being rented, he will be able to stay there.

Another family, from Iraq, reported the sense of pride, excitement and connection they feel in living in a busy, noisy street, opposite a suburban shopping centre - a location other Australians might feel is less than ideal. Describing a photograph of her husband and teenage son with the streetscape in the background, the mother said: "We live in Balga near a small shopping centre. It is a nice place, I feel well. People said that Balga was not a nice area but I like seeing the constant come-and-go of people at the shops ...There are often police sorting out problems. We like the action - there's always something to do!'. That this 
family derives a sense of comfort and belonging from such an outlook is perhaps surprising, given that they have fled a war-torn country to seek sanctuary in Australia. It may be that the element of order evident in the way the traffic moves, the presence of the police and the flows of people into and out of the shops, provides a contrast to the experience in Iraq, and is a constant reminder of the security felt here.

\section{Sociality and Commensality}

The most striking theme in analysis of the photographs was the ways in whichhome was represented as a hub for the family. Most of the images of home contained people. Among them was an image of a Burmese family dressed in traditional Karen clothing to represent their pride in their ethnic background, but withtouches of more obviously Australian ways of life evident - a skateboard, camera, Colorbond fencing and clothesline all indicated that this was a different space fromthat encountered in Burma. The same family also represented the differences inhome life between Burma and Australia with a blurry picture of members of the family posing proudly with cleaning equipment (vacuum cleaner, mops, buckets), none of which they said they would have dreamed of owning before coming to Australia (see Figure 2). This family, the same one quoted above who wanted tosend a photograph of their house back to friends in the refugee camp, expressed agreat deal of pride in their home, and wished to illustrate this by showing the 20 objects they use to clean it. The father said of this picture and another: "My daughter has a duty to clean the house. They are happy to clean ... My children all cleaning the house. We never had these tools".

Many of the images of family also contained food. Figure 3 is a single photograph selected from many of families sitting at dining tables or in the lounge room. Here the family of an Iraqi refugee is shown, in the photographer's words, "returning to a normal life". She said: "I am very happy to be with my family. I waited one and a half years before the whole family came to Australia. This was our first Ramadan together". The image shows the family sharing a "Middle Eastern" style meal with salad, pita bread, yoghurt and a vegetable, meat and rice

dish. Reproducing family and religious rituals, and foods, such as this, were an important part of recreating home for the refugee families in the study (see Gabaccia 1998). 


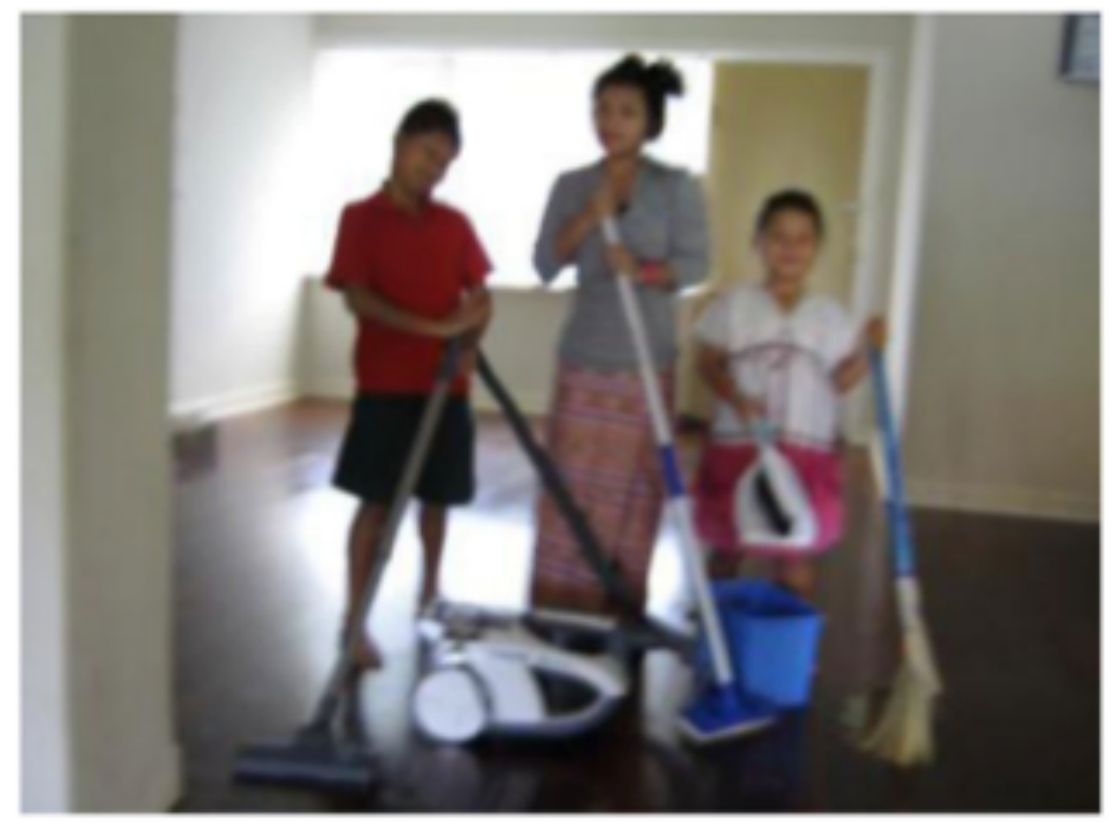

Figure 2. Image taken by male, Burma, 1.3 years in Australia. He is 55 years old and lives in a three- bedroom house with his three children.

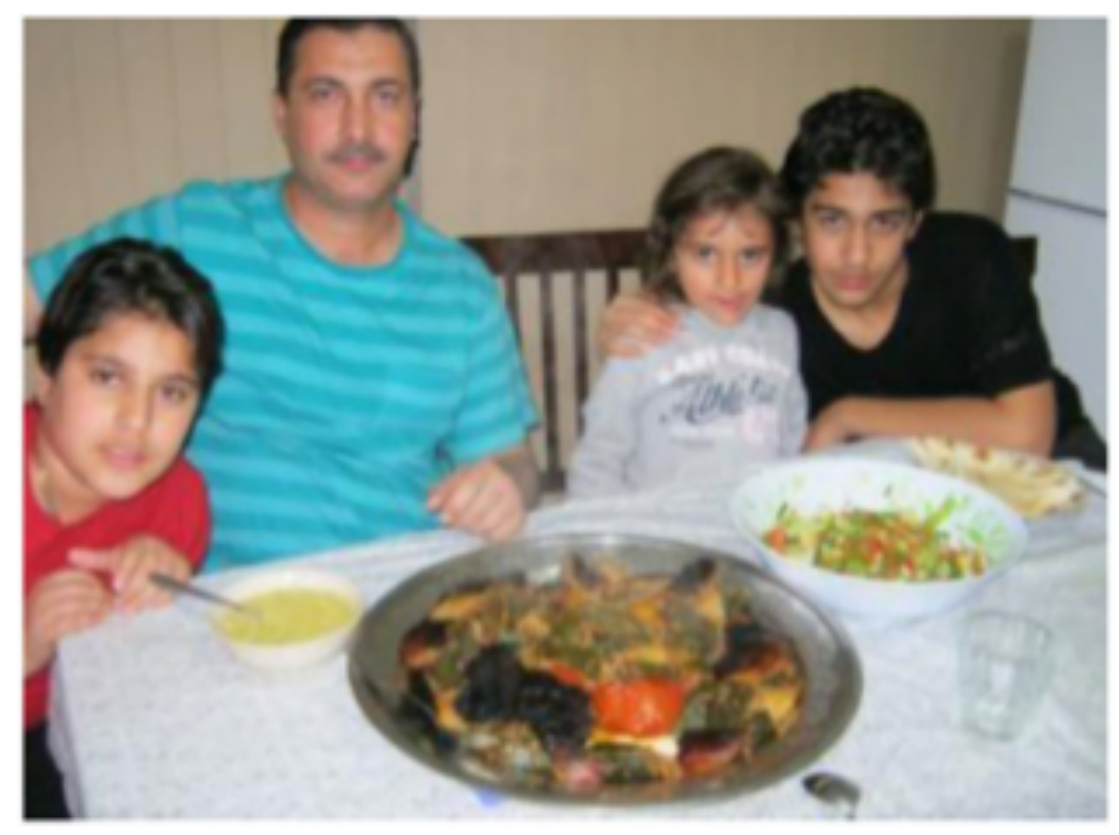

Figure 3. Image taken by female, Iraq 1.5 years in Australia. She is 39 years old and lives in a three- bedroom house with her husband and three children. 
The uses of the space of home were somewhat different among some families, and illustrated that home is more than simply bricks and mortar. Here (Figure 4), a Sierra Leone family represents the opportunity to relax together that is offered by the safety of their backyard. The photographer noted the family is so busy during the week working long hours that they often do not see each other sufficiently. However, they try to make opportunities to spend time together. One of the daughters explained that sometimes she likes to take a mattress outside to read and study: "We sit and talk out there too. Being busy is just the life in Australia. If you work, you can make progress". Thus, "home" is time and space away from work. This use of space, and particularly the transporting of bedroom furniture to the backyard, results in a somewhat surprising image. The presence of the laptop and mobile phone may illustrate the importance of these technologies for staying connected with family and friends not co-present in Australia (Wilding 2006; see also below). The physical intimacy and opportunity for rest, yet simultaneously recreation and communication, that a mattress in the backyard offers, are all captured in this image.

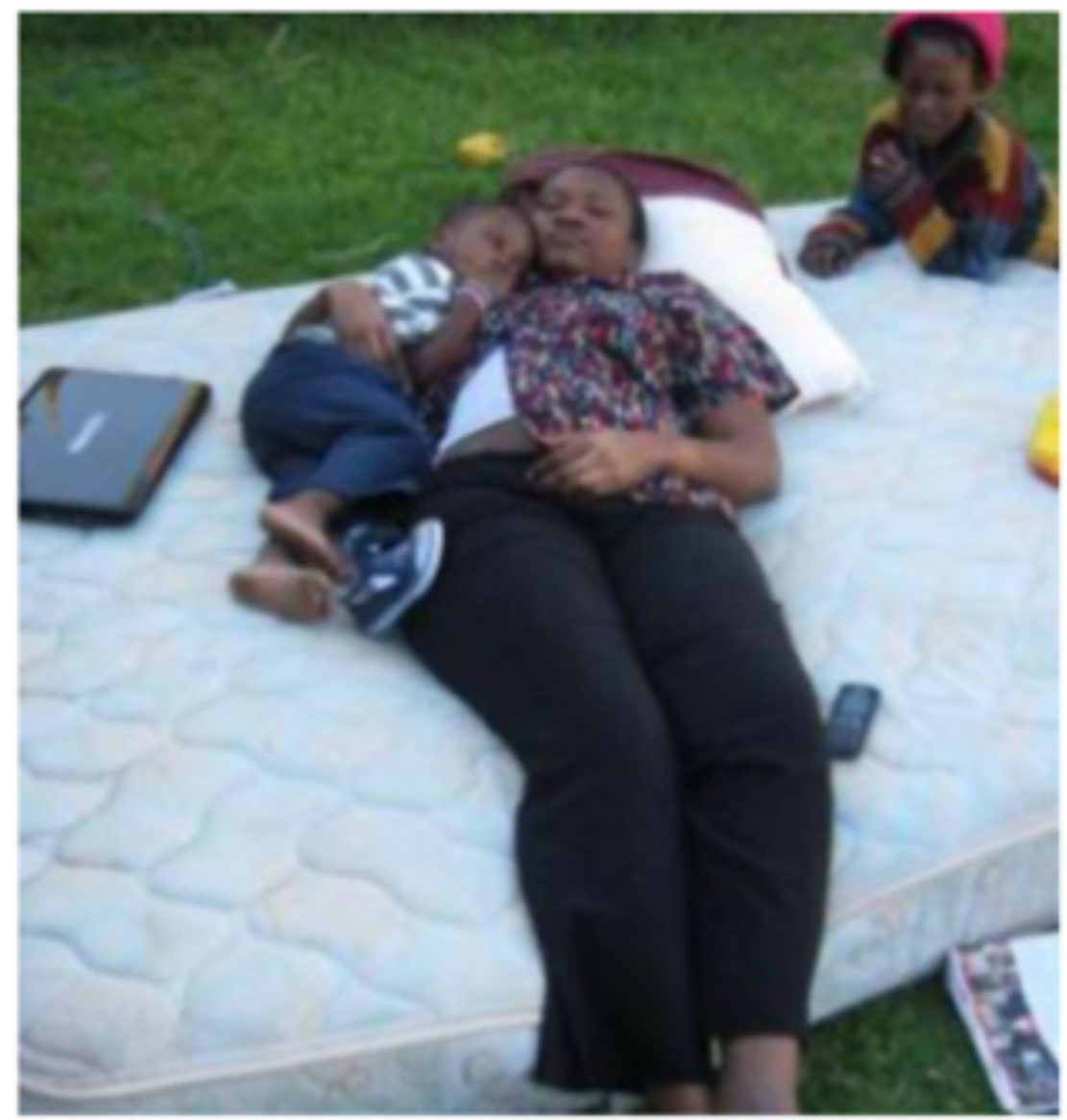

Figure 4. Image taken by male, Sierra Leone, 1.5 years in Australia. He is 41 years of age and lived in a five-bedroom house with his wife, five children and grandchild. 
Another family described how in the safety of their home in Australia they are able to connect with friends and family around the world. The mother caught on camera the daily ritual of sitting with her family in their lounge room, each member with separate laptops, chatting online to friends back in their country of origin (Figure 5). She said: "We feel we are with them in Iraq and Jordan - we feel connected. All of our feelings are with Iraq". This representation of home both resonates with Massey's notion of places as nodal in networks of social relations unbounded by territory, with intersecting social relations occurring in intersecting activity spaces (Easthope 2004). However, the photographer's commentary demonstrates the ambivalence of this concept as applied to refugees where the social relations being engaged in are stretched beyond the bounds of what might be seen as home space.

Overwhelmingly, the photographic images offered under the theme of "my home" taken positive representations of how material space produces the emotional and social space of "home", which almost invariably occurs within a "house"(in the images - bedroom, lounge, dining room and backyard). The material space offered the site within which refugees enacted their new lives adjusting to new ways of living and adapting old ways to new. These were evident in images of bathing, cleaning, spending recreation time, eating, communicating and so on. These practices are the everyday foundations of home-making - the active making

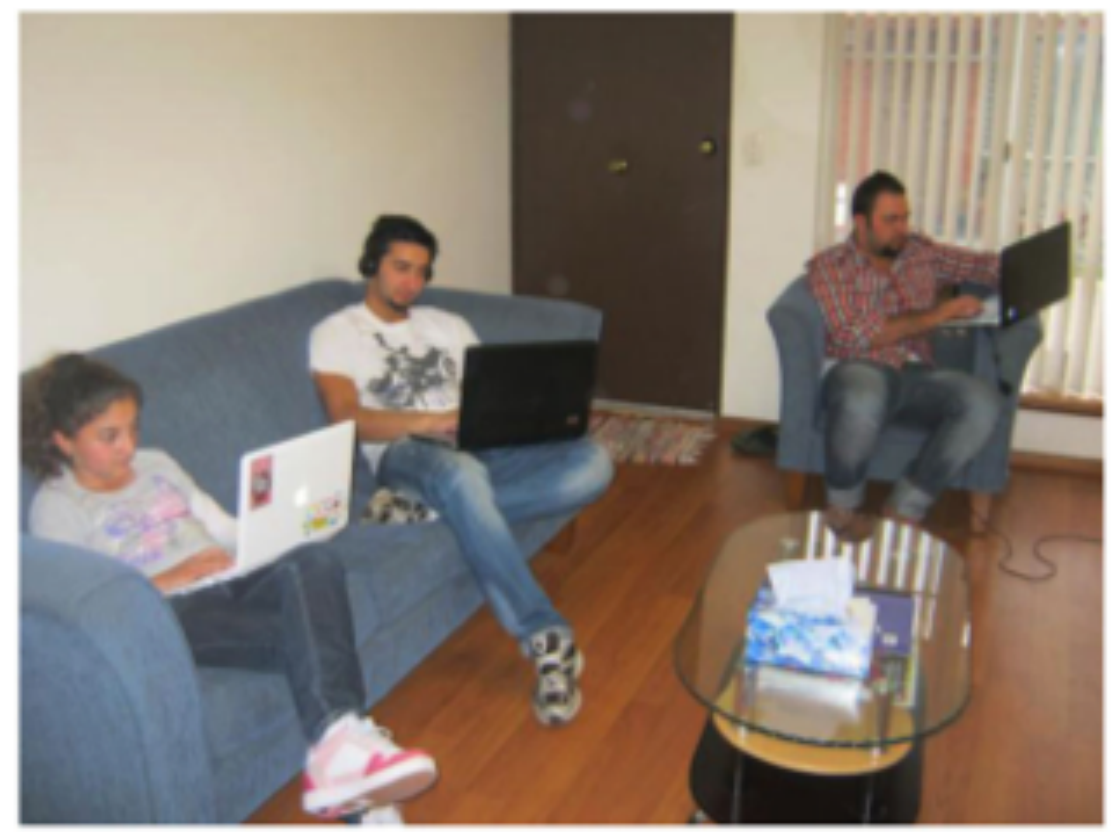

Figure 5. Image taken by female, Iraq, 9 months in Australia. She is 46 years of age and lives in a three- bedroom house with her husband and three children. 
of place where the physical construction is worked on to mould it into something the participants felt attached to and that helped them to define themselves (Easthope 2004; Massey 1995). The images told of solidity, strength, safety, quietness, and order. Most clearly they told of people, illustrating the ways in which "home is where the heart is". While the instruction had been to take pictures of "my home", images of the family within the home, and the emotions associated with family - belonging and security - were the most common. But coupled with this were the more staged photos, demonstrating opportunity and gratitude. These elements feature in the notion of ontological security - evidence of the ways in which a secure sense of oneself and one's place in the world is being re-made, adapted to, and trust in one's surroundings is being regained.

These images suggest that the physical and social space of home is being successfully re-made within the houses available to refugees settling in Western Australia, even among those refugees who have been here less than two years, producing the sort of ontological security necessary to build a full life, and to demonstrate successful refugee settlement (Ager and Strang 2008). However, there were also many stories of housing insecurity, more often told through the interviews and focus groups. Some of these issues are outlined below.

\section{Housing Insecurity}

While the images from the photovoice project told a relatively positive story of home-making within the physical space of the house/garden, when asked about housing experiences specifically, humanitarian entrants and service providers identified significant barriers to housing security, reflecting much research in the UK (Phillips 2006; Zetter and Pearl 1999). All participants lived in rental propertiesapart from one who was in a government-funded Homeswest house (public housing). None had bought a house, nor did any speak of aspirations to home ownership. This is both surprising (home ownership is known as the great Australian dream and thus successful integration might presuppose home ownership) and unsurprising (these are refugees who have been in Australia for four yearsat most, perhaps not enough time to purchase or consider purchasing a home). Since almost all participants were in the rental market, the instability of that market was the main point of discussion. Many, particularly those with fewer English skills, reported experiencing difficulty finding suitable housing after the initial support period, causing considerable stress, which compounded, and was compoundedby, a range of other settlement issues. Given the need to re-establish ontological security, the experience of, fear of and cause of, movement between abodes, were the most salient issues that arose from the interviews and focus groups. Despite the photovoice images that suggested a level of security arising 
from their housing situation, interviews and focus groups indicate housing insecurity is one of the major settlement challenges that has flow-on effects in many other areas, as this service provider outlines.

That would be the most difficult issue ... I just think housing is so importantbecause it reflects on everything else. Employment, education, and so one of the issues we always address is the fact that people in private rentals are often only getting a six month lease. So, they have a house in Girraween, they've moved to Koondoola, the children have to move schools. So that's a cost involved in buying new uniforms, but it's also a cost to the children's education ... But of course because housing is such a big issue and such a financial burden, the kids' education is secondary. Like, it doesn't matter whether they are going to school, as long as we've got a house. So that is an issue that is very broad. (Service Provider)

Among the reasons for movement were issues around affordability, size and quality, location, discrimination, and legal and structural matters. Each is dealt with briefly below.

\section{Affordable Housing - Movement and Spatial Distribution}

Location is an important determinant in housing decisions for refugees (Netto et al. 2001). For some, being in a location where there is a sense of community was important. Some expressed satisfaction with where they currently lived. Being in anarea that was close to culturally appropriate services, schools, TAFE (technical colleges), community groups and places of worship were all highlighted as important.

Interviewer: Do you like living in Mirrabooka?

Respondent: Yes, we think Mirrabooka is a good area to live because all the services are nearby such as shopping, school, TAFE, Halal meat and Halal restaurants, the mosque and most of Muslim people live in Mirrabooka and surrounding suburbs. I think it is the most suitable area for us because we can't drive. (Male, Ethiopia, four years in Australia)

However, as other studies in Australia have found (Berta 2012; Beer and Foley 2003; Burgermeister, Kitching, and Iscel 2008; Kelly 2004), the lack of affordable housing means refugees move frequently between properties. In our study, participants reported living in up to seven properties in two years, making it difficult to establish a sense of home. Participants on social support benefits (known as Centrelink) spoke of their struggle to make ends meet after paying their rent. Costs, coupled with issues around the quality of housing, safety and disagreements with neighbours or real estate agents, were key reasons for multiple 
moves.

Interviewer: What were your reasons for moving?

Respondent: Reasons for moving were when I arrived from Africa my husband was sharing a house with someone so we had to move to Nollamara. In Nollamara the house was old and leaking so we had to move to Balga. The reasons I want to move house now - my agency they don't understand us. Every six months they increase the rental fee money. I am not happy with them. They are not cooperative so we want to look for a cheaper house. (Female, Sudan, two years in Australia)

Interviewer: Since settling in Australia where have you lived?

Respondent: I have moved from place to place since being in the country. I have been to a flat house, then into a lodge where my neighbours weren't happy with me. I went to a third house that was close to the main road and I didn't want it because of my little children and actually I'm now in the fourth house ... I hope to stay in this house as moving has a lot of problem ... (Male, Congo, three years and five months in Australia)

A number of participants spoke of their experiences with burglary and of feeling unsafe with children in high-rise apartments, which motivated them to move to another location.

Interviewer: Since settling in Australia where have you lived?

Respondent: We have lived in Morley after that I moved to Balga and from

Balga to Mirrabooka ... We moved from Morley because it was a temporary house and it consists of two bedrooms only. After that we moved to Balga in a very nice unit but I didn't like the suburb and I felt that it is not safe for my children so we moved again to Mirrabooka.

Interviewer: Do you like living in Mirrabooka?

Respondent: It was but about two months ago we had robbers breaking in and from that time and we were scared. (Male, Palestine, two years in Australia)

While being close to community members, jobs and services were important factors in deciding where to live, participants often had to compromise on locationdue to high rental costs. The difficulty of finding affordable housing in areas close to service providers and schools was seen as a serious issue by service providers. As rents increase, people are becoming more dispersed, and without 
adequate transport, service providers feared they are missing out on basic services to which they are entitled.

There is not enough provision for housing for the low-income families. Also transportation is a big problem. You're quite limited really to where you can house people, because we have to be aware of where they have got to go to school. There are not enough IEC (Intensive English Centre) schools around so that we can use other areas. And we don't want the children to be catching two trains and a bus. Sometimes they do though, to get to school. It's a big problem. (Service Provider)

Service providers noted the spatial distribution of humanitarian entrants across the Perth metropolitan region due to them moving to increasingly distant suburbs insearch of lower rents. This makes servicing clients, who may be living $40 \mathrm{~km}$ fromthe main service hubs, difficult (some are now settling in satellite towns $60 \mathrm{~km}$ from the $\mathrm{CBD}$; others are moving to regional areas 4 hours drive away). As well as a lack of services, refugees settling in these areas are increasingly isolated. One older woman, who had moved to a town three hours south of Perth to be with her family, who inturn had moved there because of work and cheaper rent, spoke of the social isolation she felt not having friends or community members to talk to.

Unlike the participant who was planting flowers in the security that hewould able to remain in his house, the above participants chronicled a series of issues, mostly outside their control, that meant that they had had to move regularly. Their inability to "put down roots" in terms of the physical space they encounter produced a sense of liminality and ongoing dislocation, making settlement impossible.

\section{Lack of Housing Stock - Size and Quality}

The lack of appropriate housing was identified as a problem, particularly for single men and large families. Single men are more likely to have arrived on boats and sought asylum in Australia, and their differential access to services and support may exacerbate their difficulties in finding housing.

As seen in the quote below from the father of a family of six living in a three bedroom, one bathroom, home, these participants perceive their rejection by realestate agents due to their large families as a form of discrimination.

Interviewer: How did you find this house and who helped you?

Respondent: Actually we struggled a lot looking for a house. We went to different real estate agents and we filled out many application forms but we used to get refused all the time. I think it is because we have six kids that 
makeseveryone avoid renting to us. After that we went to Homeswest and asked them to help us because we were already on their waiting list but they advised us that they can't do anything. Eventually one of our Ethiopian friends got a Homeswest house so he talked to the owner of his rented house to accept us. (Male, Eritrea, four years in Australia)

The poor quality of many of the houses in the lower end of the market also contributed to frequent moves between rental properties. Some participants spoke of issues such as leaking taps, insect-infested rooms and the lack of response by real state agents. For some participants, the poor housing conditions were met with a profound sense of indignity.

In the photovoice exercise participants represented aspects of housing insecurity through images of inadequate maintenance (leaky taps, torn linoleum and an image that was strikingly stark in its simplicity - a legal "notice of termination" document). The photographer said of this latter image: "This is the biggest problem for many refugees. Home is not stable as there is always the possibility that you may have to move on ...". In Image 6, a child cooking outdoors on a gas burner due to the stove not being repaired for four months, the participant said: "We always pay our rent on time but the rental company does not fulfil its maintenance obligations. Whenever we need something fixed they say they have to wait for a government rebate. It takes weeks before they come out and get anything fixed. It took 4 months for repairs to our broken stovetop. As they did not come out and fix it, we were forced to buy an outdoor gas burner to use just so we could cook our food. We stopped complaining now - nothing changed when we tried. We will hopefully move by next year". This sense of helplessness in the face of bureaucracy adds to the insecurity felt. 


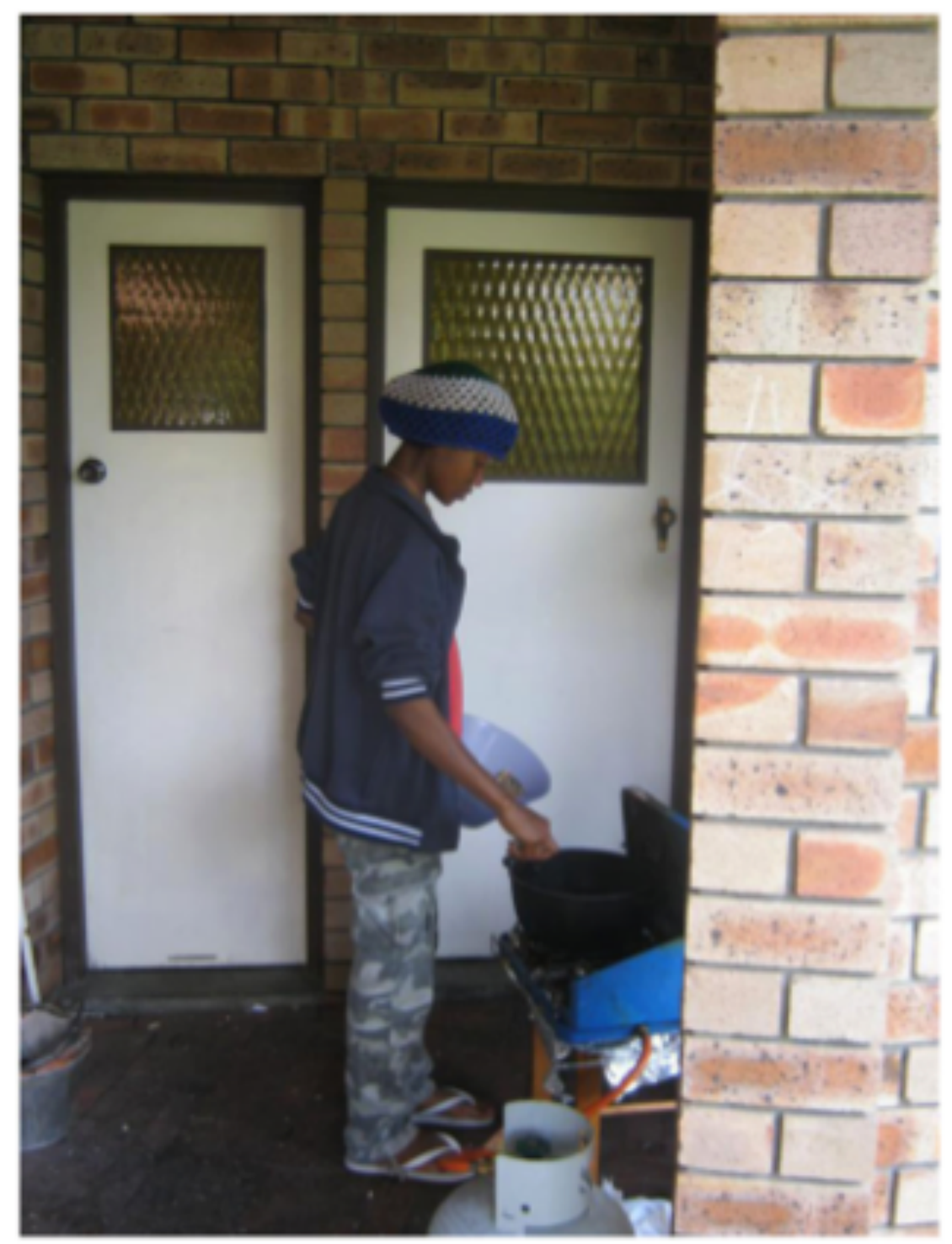

Figure 6. Image taken by male, Sierra Leone, 1.5 years in Australia. He is 41 years of age and lives in a five-bedroom house with his wife, five children and grandchild.

Some participants relied on friends and family to house them while issues were being resolved or new homes sought, resulting in a sense of instability and uncertainty.

Interviewer: Could you tell me, why did you move?

Respondent: I moved because the flat was in a very bad condition. It has a very dirty old carpet; I couldn't even sleep because I have asthma. Also the bathroom basin was broken which was very dangerous for my daughter. We couldn't stand being there so I took my family and stayed in my uncle's house for about 20 days until [a service provider] found me another house 
in Westminster. (Male, Iraq, four years in Australia)

While some participants were extremely happy with the condition of their houses, as illustrated in the images above, one participant noted that: "All refugees have dark, cold homes when they come. This was my only suffering here in Australia". The poor condition of the transitional house offered to the participant below is described as the worst experience of settling in Australia, being undignified and terrifying. Her comment reflects the cultural expectation of better treatment of strangers.

The shock we faced at the moment we arrived here - the accommodation was the worst. Unhealthy and filthy above expectation and smelly ... also a lot of missing things there, no curtains and its very quiet and during nights it was terrifying. The accommodation was very bad and had a bad psychologicalimpact on us. And until today we have a vivid memory about those days. Whatever shocking events we had been exposed to in Iraq this is the worstone. The stranger when he comes he expects to have respect and more concern. The refugee does not mean he is a poor person, the refugee mean he has a difficulty in his country and he is forced to leave so I think the organisation dealing with refugee accommodation should pay attention to this matter. (Female, Iraq, 9 months in Australia)

Similarly, another participant spoke of the negative social conditions they were exposed to in the transitional accommodation offered. As an introduction to life in Australia, such conditions (drug and alcohol abuse, violence) would be confronting. One would find it difficult to embark on a home re-building project in such a housing situation.

Interviewer: Since coming to Australia where have you lived?

Respondent: ... we lived in H ... Street Fremantle. But that apartment is the government house, and unfortunately some people are drunk, use drugs, hang around outside from midnight till morning, talking very bad words, there is broken glass, fighting, people take a knife, something like that. Just two weeks we stayed there, then we came here, now the end of this month we have to leave and find another place. (Iran, Male, one year in Australia)

\section{Racial and Religious Discrimination}

As has been found in the UK (Phillips 2006), the perception of discrimination in housing was identified by a number of refugee participants, and the issue of discrimination based on race or religion was also a point of considerable discussion in the focus groups with service providers. To illustrate this, one spoke 
of the direct discrimination one of his organization's Sudanese housing support workers experiences when he views properties for clients without wearing the agency name badge.

He's [Sudanese housing support worker] been abused by other people waiting to view a house. And he's finding he's going in and the real estate agent will be handing out forms and just ignores him. And, he walks up and if he's got a badge on, he's got his [official service provider organisation] badge on, then he said that the attitude is so different. So I'm saying to him, "look, document this". So it's, really, covert racism. It's not like someone saying "get out of here, you're African, we don't want you here" but it's quite blatant as well. And he was quite upset by it. (Service Provider)

Service providers suggested the current complaints' system is ineffective as it relies on humanitarian entrants lodging a written complain.

Participants reported that while REIWA (the Real Estate Institute of Western Australia) offers cultural awareness training to real estate agencies, which addresses issues around racism, it is not mandatory and therefore ineffective.

\section{Legal Matters}

A number of legal matters were identified which accentuated the insecurity and stress refugees feel in attempting to re-make home. At a general level, the challenge of understanding lease agreements and related rights and obligations when not fully literate in English caused significant problems. Additionally, the need for Australian housing references, the insecurity associated with short-term leases, and the new "option fee" system whereby a fee must be paid to be considered as an applicant for a rental, caused hardship.

\section{Discussion and Conclusions}

It has been suggested that home ownership, a cultural imperative known as "the Australian Dream", is important for refugees' successful adjustment and integrationboth socially and economically (Ager and Strang 2008; Forrest et al. 2012 , 16). Certainly having access to secure housing is vital for the development of ontological security, to assist with the process of rebuilding trust in one's surrounding and confidence in how to "be" in the world; and this is what is owed by signatories to the UNHCR Convention on the Rights of Refugees. This paper offers evidence tosupport the significance of housing for the development of a sense of belonging, a fundamental indicator of successful settlement (Ager and Strang 2008).

Whether "secure housing" means "home ownership" and whether 
ownership is a pre-requisite for ontological security remains a matter of debate (see Hiscocket al. 2001; Kearns et al. 2000). The sense of pride and safety associated with home represented in the images from the photovoice project indicates that for many humanitarian entrants to Western Australia, their houses are indeed homes, which offer a significant source of ontological security, despite these homes being rented, rather than owned, and despite the various difficulties faced in the housing marketmore generally. This sense of security can be seen in the photographic images inthe remaking of home as a place of connection with others, of personal pride, of comfort and leisure, of family and commensality. These images suggest a developing "topophilia", an affective bond between person and place, a concept developedby Tuan and Bachelard (see Easthope 2004) whereby a conscious re-making ofplace is occurring. In the commentary about these photographs, the word "happy" appears repeatedly, suggesting that participants are highly satisfied with their housing experiences, and getting on with the process of re-building their lives from within these spaces.

However, some of the challenges in relation to housing identified in the inter-views and focus groups suggest the re-making of home, and successful settlement through turning one's place of abode into a personal place of sanctuary and positive feeling, is not so simple. While levels of satisfaction and appreciation expressed by refugees for even the most basic of housing were positive, and for many it appears ontological security is built around simply having a roof over one's head, having family close by, and the prospect of a stable future, the experiences of difficulty regarding affordable housing, insecurity of tenure, lack of appropriate housing, discrimination and legal issues, resulted in a sense of alienation and insecurity for many. The words used to describe their feelings as a result of these conditions - dangerous, not happy, problems, not safe, scared, limited, struggle, refusal, shock, bad psychological impact and upset - are suggestive of the negative emotions associated with the housing experience that would serve as a barrier to the re-buildingof home.

As housing is seen as affecting the ability to settle successfully, it clearly deserves policy attention. While numerous reports and papers have recommended urgent interventions to alleviate the difficulties refugees face in the housing market in Australia (OMI 2009; RCOA 2010; SCOA 2012; WEAOC 2009), little has occurred in terms of action. Our findings support many of these recommendations regarding cost, quality, adequacy, security and availability, as well as the need for more training for real estate agents and humanitarian entrants, and more community housing options. Such interventions would do much to produce the feeling of well-being resulting from security of one's social and material environment, enabling a sense of control, constancy and positive identity development (Dupuis and Thorns 1998, 29; Easthope 2004; Padgett 2007). However, it should not be ignored that refugees are generally making the best of 
what is available to them in terms of housing, turning these spaces into "home", and getting on with the job of re-building their lives, despite the difficult circumstances in which many find themselves. 


\section{References}

Abu-Duhou, I. (2006). Engagement of the African community in the Northern Territory: Their Settlement, Education, Workforce And Community Participation. The Ian Potter Foundation Principal Research Fellow in the Economics of Education, School for Social and Policy Research, Charles Darwin University. http://www.cdu.edu.au/sspr/documents/EngagementoftheAfricanCommunity FullReport.pdf

Ager, A., ed. 1999. Refugees: Perspectives on the Experience of Forced Migration. New York: Cassell.

Ager, A., and A. Strang. 2008. "Understanding Integration: A Conceptual Framework." Journal of Refugee Studies, 21 (2): 166-191.

Ahmed, S., C. Castada, and A-M. Fortier. 2003. Uprootings/Regroundings: Questions of Home and Migration. Berg Ebook.

Association for Services to Torture and Trauma Survivors. 2008. Hidden Homelessness: The Impact of Homelessness on Newly Arrived Youth. Perth: Association for Services to Torture and Trauma Survivors.

Atem, P., and L. Wilson. 2008. "Housing Pathways for African Refugees in Australia: Towards an Understanding of African Refugee Housing Issues", 9. http://www.tasa.org.au/conferences/conferencepapers08/Migration,\%20Ethni city\%20and\%20Multiculturalis m/Atem,\%20Paul\%20-\%20Housing\%20pathways.pdf

Australian Survey Research Group. 2011. Settlement Outcomes of New Arrivals Report of Findings: Study for Department of Immigration and Citizenship. Sydney: Australian Survey Research Group.

Beer, A., and P. Foley. 2003. Housing Need and Provision for Recently Arrived Refugees in Australia. Melbourne: Australian Housing and Urban Research Institute, Southern Research Centre.

Berta, L. 2012. Making it Home: Refugee Housing in Melbourne's West. Melbourne: Footscray Community Legal Centre.

Blunt, A., and R. Dowling. 2006. Home. London: Routledge.

Burgermeister M., B. Kitching, and N. Iscel. 2008. Housing Crisis Committee for Culturally and Linguistically Diverse Communities. Perth: Shelter WA and Tenants Advice Service (WA). 
www.shelterwa.org.au/publications/papers_reports/2008/Gaps_in_Housing and_Support_for_Humanitarian_Communities.pdf

Brun, C. 2001. "Reterritorializing the relationship between people and place in refugee studies." Geografiska Annaler 83: 15-25.

Calhoun, C. 2007. Nations Matter: Culture, History, and the Cosmopolitan Dream. New York: Routledge.

Cooper Marcus, C. 1997. House As a Mirror of Self: Exploring the Deeper Meaning of Home. Berkeley, CA: Conari Press.

Carter, T., C. Polevychok, A. Friesen, and J. Osbourne. 2009. The resettlement experience of refugee households in Winnipeg: A three year trajectory of housing and neighbourhood experiences. Prepared for the Homeless Partnering Secretariat of HRSDC. Ottawa

Coventry, L., C. Guerra, D. Mackenzie, and S. Pinkney. 2002. Wealth of All Nations: Identification of Strategies to Assist Refugee Young People in Transition to Independence. Hobart: A report to the National Youth Affairs Research Scheme, Australian Clearinghouse for Youth Studies.

COAG Reform Council. 2011. "Affordable Housing 2010-11: Comparing Performance Across Australia." http://www.coagreformcouncil.gov.au/reports/docs/ah_comparing_10_11/Ch apter2_Housing_10-11.pdf

Demographia. 2011. 8th Annual Demographia International Housing Affordability Survey: 2012 Ratings for Metropolitan Markets (Data for 3rd Quarter 2011). http://www.demographia.com/dhi.pdf

Douglas, M. 1991. "The Idea of Home: A Kind of Space." Social Research 58 (1): 287-307.

Dupuis, A., and D. Thorns. 1998. "Home, Home Ownership and the Search for Ontological Security." The Sociological Review 46 (1): 24-47.

Dupuis, A., and D. Thorns. 1996. "Meanings of Home for Older Home Owners." Housing Studies 11(4): 485-501.

Easthope, H. 2004. “A Place Called Home." Housing, Theory and Society 21 (3): $128-138$.

Ferguson, B., and E. Pittaway, eds. 1999. Nobody Wants to Talk About It: Refugee Women's Mental Health. Culture and Mental Health. Parramatta: 
Transcultural Mental Health Centre.

Flanagan, J. 2007. Dropped From the Moon: The Settlement Experiences of Refugee Communities in Tasmania. Hobart: Social Action and Research Centre, Anglicare.

Fraser, K. 2009. Out of Africa and into Court: the Legal Problems of African Refugees. Footscray Community Legal Centre, Melbourne.

Forrest, J., K. Hermes, R. Johnston, and M. Poulsen. 2012. "The Housing Resettlement Experiences of Refugee Immigrants to Australia." Journal of Refugee Studies. doi:10.1093/jrs/fes020.

Fozdar, F. 2012. "Beyond the Rhetoric of Inclusion." In Cultures in Refuge: Seeking Sanctuary in Modern Australia, edited by Anna Hayes, and Robert Mason. Farnham: Ashgate, 49 - 66.

Fozdar, F., and L. Hartley. in press. "Civic and ethno belonging among recent refugees to Australia." Journal of Refugee Studies.

Francis, J. (2009). "You Cannot Settle Like This.” The housing situation of African refugees in Metro Vancouver, Metropolis British Columbia, Centre for excellence for research on immigration and diversity, working paper series, 9(2). http://mbc.metropolis.net/assets/uploads/files/wp/2009/WP09-02.pdf.

Gabaccia, D. 1998. We Are What We Eat: Ethnic Food and the Making of Americans. Cambridge, MA: Harvard University Press.

Giddens, A. 1993. The New Rules of Sociological Method. Cambridge: Polity Press.

Gilbert, N. 2001. Researching Social Life. London: Sage.

Goodwin-Gill, G. 2009. "Refugee or Asylum: International Law and the Search for Solutions to the Refugee Problem." In Refuge or Asylum: A Choice for Canada, edited by H. Alderman and C. Lanphier, 34-50. Toronto: York Lane Press.

Hiscock, R., A. Kearns, S. Macintyre, and A. Ellaway. 2001. "Ontological Security and Psycho-Social Benefits From the Home: Qualitative evidence on Issues of Tenure." Housing, Theory and Society18: 50-66.

Hugo, G. 2011. "A Significant Contribution: Economic, Social and Civic Contributions of First and Second Generation Humanitarian Entrants." http://www.immi.gov.au/media/publications/research/_pdf/economic-social- 
civic-contributions-booklet2011.pdf

Ingleby, D., ed. 2005. Forced Migration and Mental Health: Rethinking the Care of Refugees and Displaced Persons. New York, NY: Springer Science and Business Media.

Jacobsen, K., and L. Landau. 2003. "The Dual Imperative in Refugee Research:

Some Methodological and Ethical Considerations in Social Science Research on Forced Migration.” Disasters 27 (3): 185-206.

Joanou, J.P. 2009. "The Bad and the Ugly: Ethical Concerns in Participatory Photographic Methods with Children Living and Working on the Streets of Lima, Peru." Visual Studies 24: 214-223.

Journal of Refugee Studies 2007. Special issue: Refugee Research Methodologies, 20 (2).

Karlsson, J. 2001. "Doing Visual Research with School Learners in South Africa." Visual Sociology 16: 23-38.

Kelly, E. 2004. A New Country - But No Place to Call Home: The Experiences of Refugees and Asylum Seekers in Housing Crisis and Strategies for Improved Housing Outcomes. Melbourne: Hanover Welfare Services.

Kearns, A., R. Hiscock, A. Ellaway, and S. MaCintyre. 2000. “'Beyond four walls': The social-psychological benefits of home: Evidence from West Central Scotland." Housing Studies 15 (3): 387-410.

Kearns, A. R. Hiscock, A, Ellaway, R. and S. Macintyre. 2000"Beyond four walls" - the psychosocial benefits of home: evidence from West Central Scotland. Housing Studies. 15 (3): 387-410.

Kissoon, P. 2010. "From Persecution to Destitution: A Snapshot of Asylum Seekers' Housing and Settlement Experiences in Canada and the United Kingdom.” Journal of Immigrant \& Refugee Studies 8(1): 4-31.

Mackenzie, C., C. McDowell, and E. Pittaway. 2007. "Beyond 'do no harm': The Challenge of Constructing Ethical Relationships in Refugee Research." Journal of Refugee Studies 20 (2): 299-319.

Malkki, L. 1992. "National Geographic: the Rooting of Peoples and the Territorialization of National Identity among Scholars and Refugees." Cultural Anthropology 7 (1): 24-44.

Massey, D. 1995. "The Conceptualisation of place". In A Place in the World? 
Places, Cultures and Globalisation, edited by D. Massey and P Jess, 45-85. Oxford: Oxford University Press.

May, T. 1997. Social Research: issues, methods and process. Buckingham: Open University Press.

Morrow, V. 2001. "Using Qualitative Methods to Elicit Young People's Perspectives on Their Environments: Some Ideas for Community Health Initiatives." Health Education Research 16 (3): 255-256.

Murdie, R. A., A. S. Chambob, D. J. Hulchanski, and C. Teixeira. 1995. Housing Issues Facing Immigrants and Refugees in Greater Toronto: Initial Findings from the Jamaican, Polish and Somali Communities The Housing Question of the 'Others': Habitat II Research Conference Ankara, Turkey, November 23-25, 1995.

Murdie, R. A. 2005. "Pathways to Housing: The Experiences of Sponsored Refugees and Refugee Claimants in Accessing Permanent Housing in Toronto." International Migration and Integration 9: 81-101.

Netto, G. 2011. "Identity Negotiation, Pathways to Housing and Place: The experience of refugees in Glasgow." Housing, Theory and Society 28 (2): 123-143.

Netto, G., R. Arshad, P. de Lima, F. Almeida Diniz, V. Patel, and R. Syed. 2001. Audit of research on minority ethnic groups from a 'race' perspective. Edinburgh: Scottish Executive

Noble, G. 2005. "The Discomfort of Strangers: Racism, Incivility and Ontological Security in a Relaxed and Comfortable Nation." Journal of Intercultural Studies 26 (1-2): 107-120.

Office of Multicultural Interests. 2009. Submission to the Department of housing Social Housing Taskforce Final Report 'More than a roof and four walls'; and 'Housing 2020: Future Directions for Affordable Housing' statement. http://www.omi.wa.gov.au/resources/publications/submissions/Housing_Sub $\underline{\text { mission }}$

Padgett, D. K. 2007. “There's No Place Like (a) Home: Ontological Security Among Persons with Serious Mental Illness in the United States." Social Science and Medicine 64: 1925-1936.

Pendergast, P. 2007. Draft Discussion Paper: Housing Issues for Humanitarian Entrants with Large Families in the South West Metropolitan Area. Shelter WA. 
http://www.shelterwa.org.au/publications/news/Refugee_Housing_in_the_S W_Metro.pdf.

Phillips, B. 2012. AMP. NATSEM Income and Wealth Report Issue 29 - The Great Australian Dream - Just a Dream?. http://media.corporateir.net/media_files/IROL/21/219073/AMP_NATSEM_Income_and_ Wealth_Report_29_The_Great_Australian_Dream2.pdf.

Phillips, D. 2006. "Moving Towards Integration: The Housing Of Asylum Seekers and Refugees inBritain." Housing Studies 21 (4): 539-553.

Pollock, S., H. K. Bhabha, C. A. Breckenridge, and D. Chakrabarty. 2000. "Cosmopolitanisms." Public Culture 12 (3): 577-590.

Prins, E. 2010. "Participatory Photography: A Tool for Empowerment or Surveillance?" Action Research 8: 426-443.

Ransley, C., and S. Drummond. 2000. Young People, Cultural Diversity and Homelessness: Discussion Paper 1/2000. Centre for Multicultural Youth Issues for the Workers for Real Access to Housing (WRATH) Working Group: Melbourne.

Rapport, N., and A. Dawson. 1998. Migrants of Identity: Perceptions of Home in a World of Movement. Berg Ethnicity and Identity Series. Oxford: Berg.

Refugee Council of Australia. 2010. Australia's Refugee and Humanitarian Program 2009-1 - RCOA submission.

http://www.refugeecouncil.org.au/r/isub/2009-10-IntakeSub.pdf.

Robinson, D., K. Reeve, and R. Casey. 2007. The Housing Pathways of New Immigrants. Bristol: Policy Press.

Said, E. 2000. Reflections on Exile and Other Essays. Cambridge, MA: Harvard University Press.

Sampson, R., and S. Gifford. 2010. "Place-Making, Settlement and Well-Being: The Therapeutic Landscapes of Recently Arrived Youth with Refugee Backgrounds." Health and Place 16: 116-131.

Saunders, P. 1990. A Nation of Home Owners. London: Unwin Hyman.

Settlement Council of Australia. 2012. "SCOA Discussion Paper: Addressing Barriers to Adequate Housing." http://www.scoa.org.au/resources/SCOA\%20position\%20statement\%20\%20Housing\%20-\%20final.pdf 
Searle, B. A., S. J. Smith, and N. Cook. 2009. "From Housing Wealth to Wellbeing?" Sociology of Health and Illness 31: 112-127.

Shaw, M. 2004. "Housing and Public Health." Annual Review of Public Health 25: 397-418.

Sherrell, K., S. D'Addario, and D. Hiebert. 2007. "On the Outside Looking In: The Precarious Housing Situations of Successful Refugee Claimants in the GVRD." Refuge 24 (2): 64-75.

Tilbury, F., S. Clark, R. Slee, and I. O'Ferrall. 2005. Listening to Diverse Voices Multicultural Mental Health Promotion Research Project - Eritrean, Ethiopian, Somali and Sudanese communities in Western Australia, East Metropolitan Population Health Unit and Murdoch University, Perth. http://www.healthyfuture.health.wa.gov.au/

United Nations. 1991. The Right to Adequate Housing. UN Commission on Economic, Social and Cultural Rights. http://www.unhchr.ch/housing/

UNHCR. 2002. Refugee resettlement: an international handbook to guide reception and integration. Geneva: United Nations High Commissioner for Refugees.

Valtonen, K. 2004. "From the Margins to the Mainstream: Conceptualizing Refugee Settlement Processes.” Journal of Refugee Studies 17 (1): 70-96.

Wang, C. C., and Y. A. Redwood-Jones. 2001 "Photovoice Ethics: Perspectives from Flint." Photovoice. Health Education and Behavior. 28 (5): 560-572.

Ward, C., B. Stephen, and A. Furnham. 2001. "Refugees." In The Psychology of Culture Shock, edited by C. Ward, S. Bochner, and A. Furnham. London: Routledge.

Western Australia Equal Opportunities Commission. 2010. Annual Report 20092010.

http://Fwww.eoc.wa.gov.au\%2FLibraries\%2Fpdfs\%2FEqual_Opportunity_C ommission_Annual_Report_2009_2010.sflb.ashx\&ei=_1NtULOQJY6RiQf w1oC4CA\&usg=AFQjCNEGfTqVHxfrMa9WZnePZC5eZ-fn 5Q\&cad=rja.

Wilding, R. 2006. “'Virtual” Intimacies? Families Communicating Across Transnational Contexts." Global Networks: A Journal of Transnational Affairs 6 (2): 125-142.

Winkler. n.d. Investigate the Issues Affecting Black African Migrant Settlement in Australia. http:// 
www.flinders.edu.au/sabs/sisfiles/developmentstudies/africa/current/caprichs iawinkler.pdf.

Zetter, R., and M. Pearl. 1999. "Sheltering on the Margins: Social Housing Provision and the impact of Restrictionism and Asylum Seekers and Refugees in the UK." Policy Studies 20 (4): 235-254. 